\title{
UNDERSTANDING LEGAL EVOLUTION THROUGH CONSTITUTIONAL THEORY: THE CONCEPT OF CONSTITUTIONAL (IN-)FLEXIBILITY
}

\author{
Elaine $\mathrm{Mak}^{*}$
}

\begin{abstract}
Why do legal arrangements for the institutions of government (legislative, executive, judicial branches) in Western liberal democracies develop faster, or in a different way, in one jurisdiction in comparison to another? In this article, it is argued that constitutional theory can help us understand the development of these legal institutional arrangements, for example in light of the changing role of national highest courts in the globalised legal context. For this purpose, the concept of constitutional (in-)flexibility is introduced, which can explain how national constitutional frameworks enable or constrain the integration of normative changes in national legal systems. Four elements encompassed by this concept are identified: the detail of constitutional norms, the modalities for revising the national Constitution, the approach to legal argumentation taken by interpreters of the Constitution, and the influence attributed to international law within the national legal system. This analytical framework is applied to the illustrative case of judicial globalisation - concerning, inter alia, the judicial use of non-binding foreign law - to explain similarities and differences concerning the way in which changes affecting the functioning of national highest courts are integrated within different legal systems. This analysis, in turn, yields some insight into the further development of constitutional theory in the era of globalisation.
\end{abstract}

Keywords: constitutional theory; legal methodology; highest courts; globalisation

\section{Introduction}

To what extent can constitutional theory contribute to the understanding of legal evolution? To begin with, some conceptual clarifications are required. Legal evolution is the term used to refer to the development of the law over time. ${ }^{1}$ Law in this definition can be understood as referring to the system of rules which are accepted by a specific community as governing the actions of the members of that community, and which are enforced through the imposition of sanctions. ${ }^{2}$ The term evolution suggests that this system of rules develops gradually over time, ${ }^{3}$ by way of changes in a society governed by the law. It has been suggested in legal theoretical literature that four causes play a role in legal evolution: (i) changes in the pressure of law-making forces exercised by the classes in a society, (ii) a clearer perception of economic needs, (iii) the development

\footnotetext{
Associate Professor of Jurisprudence at Erasmus University Rotterdam, Erasmus School of Law. Contact: mak@law.eur.nl. The research for this article was supported by a post-doctoral VENI grant from the Netherlands Organisation for Scientific Research (NWO). I would like to thank Klaus Heine for the opportunity to contribute to this special issue. Thanks are also due to Jan Schnellenbach, who acted as the discussant for an earlier version of this article at the Erasmus Law Review seminar organised in Rotterdam on 23 June 2011, and to the other participants in this seminar. I would further like to thank the anonymous reviewer of this article for useful comments, as well as Kristin Henrard and Chantal Mak. Any mistakes remain my own.

1 See P. Stein, Legal Evolution: The Story of an Idea (2009).

2 This description is based on the definition found at <http://oxforddictionaries.com>, lemma 'law'. It is well-known, however, that the definition of the concept of law is a topic of continuous debate amongst legal philosophers. This debate focuses, inter alia, on the nature of legal norms, including the distinction between law and morality and the necessity of the requirement of sanctions. The discussion of the concept of law falls outside the scope of this current article. Interested readers might refer to the extensive literature on this topic, to which famous contributions have been made by H.L.A. Hart, The Concept of the Law (1997) and R. Dworkin, Law's Empire (1986).

${ }_{3}<$ http://oxforddictionaries.com>, lemma 'evolution', meaning 2: 'the gradual development of something'.
} 
of greater moral courage by a community, and (iv) improvements in legal machinery. ${ }^{4}$ The process of legal development under the effect of these causes - which represent different normative changes affecting legal systems - can be studied from different academic perspectives. One of these is the perspective of constitutional theory.

Constitutional theory is a scholarly approach to government, which focuses upon the nature and significance of constitutions. ${ }^{5}$ A constitution is a set of fundamental norms (principles, rules and conventions) which forms the basis for the government of a specific community (in general, the community of people organised within a state). ${ }^{6}$ These underpinnings of government are visible in the constitutional law of states, namely the primary law concerning the establishment of the institutions of government, the attribution of competences to these institutions and the regulation of the relations of these institutions to one another and to the citizens. ${ }^{7}$ The idea of constitutional government is embodied in the principle of the rule of law, namely the principle that all within the state should be subjected to the law. ${ }^{8}$ In liberal-democratic states, the specific normative framework expressed in the constitution includes the traditions of democracy, rule of law, human rights protection and open government. ${ }^{9}$

This article will show how constitutional theory, based on the subject matter it covers, can contribute to the understanding of a specific aspect of legal evolution, namely the development of legal arrangements regarding the institutions of government (the legislative, executive and judicial branches). The article will address both the possibilities and the limitations of constitutional theory for the study of this aspect of legal evolution. ${ }^{10}$ The central thesis that will be defended is that the development of national institutional legal arrangements is catalysed by the constitutional framework underpinning the government of a national community. More specifically, it will be argued that extra-legal normative changes - for example of a political, economic or moral nature - are accommodated in a specific legal system through the filter of this system's constitutional framework. ${ }^{11}$ The concept of constitutional (in-)flexibility will be introduced as the analytical concept, which aids the understanding of the form and speed of this integration of normative changes into national legal systems, and which thus - amongst other things ${ }^{12}$ - helps explain the specific process of the legal development of institutions of government. ${ }^{13}$

W.M. Blatt, 'Some Principles of Legal Evolution', 23 Yale Law Journal 2, at 168 (1913).

D.J. Galligan, 'The Paradox of Constitutionalism or the Potential of Constitutional Theory?', 28 Oxford Journal of Legal Studies 2, at 344 (2008).

See in more detail hereafter, para. 2.1.

C.A.J.M. Kortmann, Constitutioneel recht (2005), at 9.

See T. Bingham, The Rule of Law (2010), at 8.

T. Koopmans, Courts and Political Institutions: A Comparative View (2003), at 7.

10 It should be noted that other academic disciplines also provide angles to study legal evolution at the constitutional level. See for example S. Voigt, Explaining Constitutional Change: A Positive Economics Approach (1999).

11 This article will focus on the functioning of the constitutional frameworks of national legal systems. However, insights from this analysis might also be relevant for the study of emerging supranational constitutional frameworks, in particular the EU legal order.

${ }_{12}$ The significance of 'constitutional (in-)flexibility' is not restricted to the development of institutional legal arrangements only. The (in-)flexibility of a legal system's constitutional framework also has a significant impact on the possible degree and speed of reforms concerning certain areas of society, such as the privatisation of public utilities in OECD countries or the reforms in European higher education systems. See for example C. Schmitt and H. Obinger, 'Constitutional Barriers and the Privatization of Public Utilities in Rich Democracies’, 7 World Political Science Review 1 (2011). In political economy literature, these implications of constitutional (in-)flexibility have been addressed inter alia by W.J. Henisz, 'Political Institutions and Policy Volatility', 16 Economics \& Politics 1 (2004); N. Hoffman, 'Political Institutions and Policy Outcomes: The Political Constraints Approach of Henisz', 8 CESifo DICE Report 53 (2010); G. Tsebelis, Veto Players: How Political Institutions Work (2002).

${ }_{13}$ The choice to focus on this concept does not mean to deny that constitutional theory also offers alternative analytical frameworks to clarify processes of legal evolution. See for example R.B. Siegel, 'Constitutional Culture, Social Movement Conflict and Constitutional Change: The Case of the de facto ERA', 94 California Law Review 1323 (2006) (relating constitutional understanding to the way in which constitutional culture enables or constrains social movement conflict); M. Jacobson, 'Understanding Legal Evolution: The Construction of the Constitutional Order in Europe', Hebrew University of Jerusalem 
Throughout this article, an example will be used in order to clarify how the legal integration of normative changes can take place through the constitutional framework of legal systems. This example concerns the trend in judicial globalisation. Globalisation relates to the increased interconnections between localities in the world - and thus people - in fields such as international commerce, environmental protection, or the guarantee of human rights. ${ }^{14}$ In the legal context, globalisation is defined as the 'trend toward world domination of specific regimes ${ }^{15}$ or, more narrowly, as the "convergence among national constitutional systems in their structures and in their protections of fundamental human rights' ${ }^{16}$ Under the effects of globalisation, defined in this legal sense, changes have developed in the understanding of the function of highest courts in national legal systems, in particular in western states. ${ }^{17}$ Supreme judicial courts and constitutional courts remain the final interpreters of legal or constitutional norms within these national legal systems. However, in addition, they have become responsible for the application of binding international and supranational legal norms at the local level. Moreover, the increase of transnational judicial networks and the availability of foreign case law have given rise to debate regarding the use of non-binding foreign law in the decision-making of highest courts. ${ }^{18}$ Globalisation has thus led to a change in the societal perception of the highest courts' role in national legal systems. Globalisation has also changed the perception that judges have of their role and their judicial decision-making in these courts. ${ }^{19}$ Constitutional legal scholarship studies these changes in order to develop a new understanding of the role of national highest courts in the globalised legal context and to develop a more systematic approach to the use of foreign law in judicial decisionmaking. ${ }^{20}$ The trend of judicial globalisation, prompting the development of the national judicial function, thus offers a point of departure for illustrating how constitutional theory, and in particular the concept of constitutional (in-)flexibility, can contribute to the understanding of legal evolution.

This article is structured as follows. Firstly, the concept of constitutional (in-) flexibility as a catalyst of legal evolution is described in greater detail, both as concerns its meaning and the elements of which it is composed (2). Secondly, it is demonstrated how the concept of constitutional (in-)flexibility can be used to describe and explain the development of institutional legal arrangements in national legal systems, focusing on the trend of judicial globalisation (3). Based on this analysis, a brief investigation is made concerning new paths for constitutional theoretical research which will enable the development of a better understanding of changes which currently affect liberaldemocratic societies (4). Finally, some conclusions are drawn regarding the possibilities and limitations of constitutional theory in contributing to the understanding of legal evolution (5).

Working Papers, (2005) <http://www.ef.huji.ac.il/publications/jacobson.pdf> (relating legal evolution to social conceptions of rights which construct a legal order through a social communication process).

14 See S. Sassen, 'Globalization or Denationalization?’, 10 Review of International Political Economy 1 (2003); J.-B. Auby, La globalisation, l'Etat et le droit (2010).

15 H.P. Glenn, Legal Traditions of the World: Sustainable Diversity in Law (2007), at 49.

16 M. Tushnet, 'The Inevitable Globalization of Constitutional Law', 49 Virginia Journal of International Law 4, at 987 (2009).

17 See in more detail hereafter, para. 3.1. A general analysis of the relationship between globalisation and the development of the western legal tradition can be found in D.B. Goldman, Globalisation and the Western Legal Tradition: Recurring Patterns of Law and Authority (2007).

${ }_{18}$ See inter alia B. Markesinis and J. Fedtke, Judicial Recourse to Foreign Law: A New Source of Inspiration? (2006); S. Muller and S. Richards (eds.), Highest Courts and Globalisation (2010); J. Allard and A. Garapon, Les juges dans la mondialisation (2005).

19 See, inter alia, E. Mak, 'Why Do Dutch and UK Judges Cite Foreign Law?', 70 Cambridge Law Journal 2 (2011).

${ }_{20}$ See, inter alia, V.C. Jackson, Constitutional Engagement in a Transnational Era (2009); C. McCrudden, 'Judicial Comparativism and Human Rights', in E. Örücü and D. Nelken (eds.), Comparative Law: A Handbook (2007), at 371. 


\section{Constitutional (In-)Flexibility: Concept and Elements}

Constitutional theory provides the concept of constitutional (in-)flexibility in order to account for the development of institutional legal arrangements in states. This section will seek to demonstrate what this concept means (2.1) and which elements it encompasses (2.2).

\subsection{The Concept of Constitutional (In-)Flexibility}

The concept of constitutional (in-)flexibility concerns the relative openness of the constitutional framework of a specific legal system as concerns the expression of normative change. ${ }^{21}$ The meaning of this concept can be explained in more detail by focusing on the separate elements of constitution and (in-)flexibility.

Firstly, the notion of constitution refers to the fundamental legal rules and principles of a legal system - namely, its Constitution - as well as the conventions which underlie these fundamental rules and principles. In a substantive sense, the Constitution is the set of norms which determines the production of general and abstract norms within the legal system. ${ }^{22}$ In a formal sense, it is the set of norms which has a supreme normative status through its formalisation as a set of norms for which the conditions of validity encompass elements other than those required for all other forms of law. ${ }^{23}$ Constitutions can be codified, like the US Constitution ${ }^{24}$ or the German Grundgesetz. ${ }^{25}$ Constitutions can also be non-codified or unwritten, like the constitution of England. ${ }^{26}$ Codified constitutions in contemporary western liberal democracies usually contain general provisions regarding the establishment and functioning of the branches of government, including the judiciary, as well as a catalogue of fundamental rights. ${ }^{27}$ Non-codified constitutional norms, such as the norms included in the English constitution, have substantive but no formal constitutional status; they determine the conditions for the elaboration of rules within the legal system, but do not have a different normative status from other rules in that legal system. Complementing the constitutional rules and principles, constitutional conventions are the unwritten fundamental norms which affect principles, determine the possible interpretations of legal norms, or formulate unspoken rules. ${ }^{28}$ An example of such an unwritten constitutional convention is the principle of the sovereignty of Parliament, which underpins the English legal system. The constitutional conventions form 'the flesh which clothes the dry bones of the law', or the muscles that make the constitutional skeleton move. ${ }^{29}$ In yet another metaphorical term: they are the Constitution's 'dark matter', ${ }^{30}$

The notion of (in-)flexibility secondly relates to a process of change. Given the role of constitutions as the basic set of rules for the governing of a specific community, they are supposed 'to be of a certain permanence'. ${ }^{31}$ However, it is also generally admitted that to endure in a changing legal context, ${ }^{32}$ and to guide legal development in such

See also E. Mak, De rechtspraak in balans (2007), in particular at Chapter 3.

L. Favoreu et al., Droit constitutionnel (2001), at 69.

Id., at 72.

$<$ http://www.usconstitution.net/>.

$<$ http://www.gesetze-im-internet.de/gg/>.

V. Bogdanor, The New British Constitution (2009), at 5.

See for example the US Constitution or the German Grundgesetz, above n. 24 and 25.

P. Avril, Les conventions de la Constitution (1997) at 12. See also L.H. Tribe, The Invisible Constitution (2008), in which the author analyses the 'ocean of ideas, propositions, recovered memories and imagined experiences' (at 9), which gives meaning to the 'visible' Constitution of the US.

29 Avril, above n. 28, at 12, citing W.I. Jennings, The Law and the Constitution (1938), at 80.

30 Tribe, above n. 28, at 210.

31 A. Busch, 'The Grundgesetz after 50 Years: Analysing Changes in the German Constitution', 9 German Politics 1 (2000), at 46.

32 Z. Elkins, T. Ginsburg and J. Melton, The Endurance of National Constitutions (2009), at 4 (arguing that the endurance of constitutions is related more to constitutional design than to the environment which hosts the Constitution). 
a changing context, ${ }^{33}$ constitutional frameworks should possess a degree of flexibility in light of changing circumstances. ${ }^{34}$ Simply put, the Constitution and its conventions should be able to catalyse legal development in a changing society. In this light, (in-)flexibility is the parameter which explains to what extent national constitutions allow for the integration of normative changes, which occur in a specific society, into the national legal framework for government. For example, the aforementioned development regarding the conception of the judicial function in a globalised world represents such a normative change. On the basis of its degree of (in-)flexibility, the constitutional framework of a specific national legal system determines how and to what extent normative changes can be integrated into this legal system. The constitutional framework of a national legal system thus enables or constrains the accommodation of normative change. The question thus arises: which factors determine the (in-)flexibility of a specific constitutional framework?

\subsection{The Elements of Constitutional (In-)Flexibility}

The (in-)flexibility of constitutions with regard to the expression of normative change is related to several elements. Two elements concern the norms which make up the Constitution. Two other elements concern the interpretation and application of the Constitution. We will see that the degree of (in-)flexibility of a specific constitutional framework depends upon the legal system's constitutional corpus of rules and the possibility of modifying these rules, as well as upon the judicial interpretation of the constitution and the influence of international law. ${ }^{35}$

\subsubsection{The Detail of Constitutional Norms}

Firstly, constitutional (in-)flexibility is determined by the degree of detail of constitutional norms. A limited degree of detail will entail a relatively flexible constitutional framework. A high degree of detail, by contrast, will lead to less flexibility. In the latter case, the Constitution will leave less scope for interpretation than in the case of less-detailed norms. In other words: the detail of constitutional norms limits the scope of discretion attributed to the interpreter of constitutional norms. ${ }^{36}$

A clear example of the constraints which the Constitution can impose through detailed constitutional norms is found in the German Grundgesetz, which contains, inter alia, a precise set of provisions regarding the organisation of the domestic court system. ${ }^{37}$ Article $101 \mathrm{GG}$, which codifies the principle of the 'gesetzlicher Richter', ${ }^{38}$ restricts the possibility of the distribution of cases amongst the courts:

\section{Article $101 \mathrm{GG}$ \\ [Ban on extraordinary courts]}

1. Extraordinary courts shall not be allowed. No one may be removed from the jurisdiction of his lawful judge.

2. Courts for particular fields of law may be established only by law. ${ }^{39}$

\footnotetext{
33 See, inter alia, M. Tushnet, Why the Constitution Matters (2010).

34 Busch, above n. 31, at 46, referring to K. Loewenstein, Über Wesen, Technik und Grenzen der Verfassungsänderung (1961), at 21.

35 See also E. Mak, 'Justice at a New Scale: Introducing a Conceptual Framework for the Analysis of Highest Courts' Role in a Globalised Context', in S. Muller and S. Richards (eds.), Highest Courts and Globalisation (2010) and Mak, above n. 21, at $105 \mathrm{ff}$.

36 See hereafter, para. 2.2.3.

37 Articles 92-104 GG.

38 See M. Fabri and P.M. Langbroek, 'Is There a Right Judge for Each Case? A Comparative Study of Case Assignment in Six European Countries’, 1 European Journal of Legal Studies 2, at 6 (2007).

39 Article $101 \mathrm{GG}$ (official translation), <https://www.btg-bestellservice.de/pdf/80201000.pdf >.
} 
The degree of detail here means that this system has less flexibility than other legal systems with respect to the integration of change. For example, this affects the possibility of specialisation within the judicial system, which, in turn, can increase the effectiveness and efficiency of the judicial process. ${ }^{40}$

With regard to the topic of judicial globalisation, liberal-democratic constitutions define the balance of powers in western legal systems, including the role of the judicial branch in this balance. These constitutions thus encompass the basic requirements regarding the functioning and the institutional set-up of the national judicial system, in which the highest courts are encompassed. As concerns the catalysis of the effects of globalisation, the Constitution can also contain rules regarding the status and conditions of application of international and supranational law within the national legal system. ${ }^{41}$

\subsubsection{The Modalities for Revision of the Constitution}

Secondly, the (in-)flexibility of a specific constitutional framework is determined by the stringency of the requirements imposed for revision of the Constitution. In academic literature, the distinction between 'flexible' and 'rigid' constitutions has been connected with this aspect of constitutional frameworks. Ferreres-Comella has observed that:

(a) Constitution is said to be formally 'rigid' to the extent that it can only be amended through political procedures that are more complex than those that are followed for the enactment and repeal of ordinary legislation. A flexible Constitution, in contrast, can be amended following the ordinary procedure. ${ }^{42}$

With regard to the broader concept of constitutional (in-)flexibility, a complicated procedure for constitutional revision will mean that it is relatively difficult to integrate normative change into a specific constitutional framework. A procedure with less stringent requirements will entail more flexibility within the constitutional framework in question. These requirements concern both the number of political actors involved in the amending process, and the percentage of votes needed for the amendment to be passed by Parliament. ${ }^{43}$

Some examples illustrate this second factor of constitutional (in-)flexibility. The Dutch and French Constitutions, for example, demonstrate relatively little flexibility. The Dutch Constitution requires an amendment to be considered by Parliament twice. Furthermore, an amendment to the Constitution can only be adopted by a parliamentary supermajority. ${ }^{44}$ In France, a constitutional amendment requires either a supermajority in the Congrès (composed of both chambers of Parliament together) or a vote by referendum. ${ }^{45}$ The Constitution is not altered very frequently in either country. The last integral amendment to the Dutch Constitution took place in 1983. The French Constitution of 1958 has been amended just 24 times since its adoption, most recently by the Law of 23 July 2008, which, inter alia, introduced the competence to constitutionally review legislative acts. ${ }^{4}$ Compared with the Dutch and French systems, the German Constitution, by contrast, contains a relatively light amendment procedure. This only differs from the normal legislative procedure in its requirement of a two-thirds voting majority for the amendment in the Bundestag and in the Bundesrat. ${ }^{47}$ Since 1949, the

40 Mak, above n. 21, at Chapter 6.

41 See further hereafter, paras. 2.2.3 and 2.2.4.

42 V. Ferreres-Comella, 'A Defense of Constitutional Rigidity', in P. Comanducci and R. Guastini (eds.), Analisi e diritto 2000. Ricerche di giurisprudenza analitica (2000), at 46.

43 Id., at 46-47.

44 See Article 137 of the Dutch Constitution.

45 Article 89 of the French Constitution of 1958.

46 Loi constitutionnelle no 2008-724 du 23 juillet 2008 de modernisation des institutions de la $V^{e}$ République.

47 Article 79(2) GG. 
Grundgesetz has been changed more than fifty times, a frequency which has led one author to exclaim that 'no constitution in the world' has been changed as often. ${ }^{48}$

It is important to note that the constitutional modalities for the revision of the Constitution cannot be viewed separately from the constitutional conventions underpinning a specific legal system. Since the 1990s, constitutional amendments in France have become more frequent as a result of the effects of a political push to modernise the institutions of the state, as well as the need to incorporate changes related to the development of the EU and international legal orders within the domestic legal system. ${ }^{49}$ In the German example, the amendments of the Constitution took place at irregular intervals. Regular changes were made during the first 25 years of the Grundgesetz's existence, followed by a period of relative stability lasting for 14 years, and then another peak which occurred as the result of the German unification. ${ }^{50}$ This suggests that alterations were made only when significant events in the social life of the community invited such changes. As a rule, the French and German legislative powers therefore seem to take a position of restraint regarding the modification of their Constitutions. In this light, constitutional conventions regarding the use of the amendment procedure should be taken into account when measuring the (in-)flexibility of a specific legal system's constitutional framework.

Inversely, constitutional conventions can be affected by revisions of fundamental rules of the legal system. The non-codified English constitution, for example, was arguably modified by the adoption of the Human Rights Act 1998. A normal parliamentary majority was sufficient for the adoption of this Act, ${ }^{51}$ which introduced the possibility of judicial examination of the conformity of Acts of Parliament in light of the rights protected by the European Convention on Human Rights (ECHR). Although no power of annulment or non-application of legal provisions has been granted to the courts, they were given the competence to issue a declaration of incompatibility of parliamentary Acts in light of the protected Convention rights. ${ }^{52}$ Such a declaration is considered to put pressure on the legislator to rectify legislative acts. Therefore, the introduction of the Human Rights Act is considered by many to have had an impact on the principle of parliamentary sovereignty. ${ }^{53}$ This example reflects a nuanced interplay between gradually changing constitutional rules and conventions. Indeed, the introduction of the Human Rights Act 1998 could only take place after a long and gradual 'incubation' of the idea of judicial human rights protection in the British legal system. ${ }^{54}$

Apart from the two previously discussed factors relating to the norms included in the Constitution, the (in-)flexibility of a specific legal system's constitutional framework depends on two factors regarding the interpretation and application of the Constitution.

\subsubsection{The Approach of the Interpreter of the Constitution}

The constitutional (in-)flexibility of a specific legal system depends on the approach to legal argumentation chosen by the interpreter of the Constitution. This interpreter can be the legislator who, through the preparation of legislative bills, will have to ensure

\footnotetext{
48 A. Roßnagel, Die Änderungen des Grundgesetzes. Eine Untersuchung der politischen Funktion von Verfassungsänderungen (1981), at 1; cited by Busch, above n. 31, at 1 .

${ }^{49}$ For an overview of these revisions, see <http://doc.sciencespo-lyon.fr/Ressources/Documents/ DocEnLigne/Constitutions/revision-constitution.html>.

50 Busch, above n. 31, at 45.

51 The Human Rights Act received royal assent on 9 November 1998. The text of the Act is available at <http://www.legislation.gov.uk/ukpga/1998/42/contents>.

52 Article 4 Human Rights Act 1998.

53 See A.L. Young, Parliamentary Sovereignty and the Human Rights Act (2009); and A. Kavanagh, Constitutional Review under the UK Human Rights Act (2009). For a contrasting view, see Bingham, above n. 8, at 165 .

54 See Bingham, above n. 8, chapters 7 and 12. Lord Bingham was a key player in this process of change. Regarding his role, see B. Hale, 'A Supreme Judicial Leader', in M. Andenas and D. Fairgrieve (eds.), Tom Bingham and the Transformation of the Law: A Liber Amicorum (2009), at 209.
} 
that the Constitution is respected. The interpreter can also be the executive power, who exercises this function through the preparation of regulations. Finally, the interpretation of the Constitution can be assumed by the judicial branch. ${ }^{55}$

The interpretation of the Constitution will affect the accommodation of normative change within national legal systems depending on the argumentative approach chosen by the interpreting authority. The German Constitutional Court, for example, initially interpreted the Grundgesetz in such a way as to limit the impact of EU law within the national legal system regarding the standards of human rights protection. ${ }^{56}$ The Supreme Court of Canada, as another example, is considered to have stimulated normative change in the Canadian legal system through its interpretation of the Canadian Charter of Rights and Freedoms. ${ }^{57}$

Since multiple actors (the legislative, the executive and the judicial branches) are involved in the interpretation of the Constitution, each of them can contribute to the (in-)flexibility of their constitutional framework of their legal system. For this reason, it is necessary to consider the relationship between these actors in the balance of powers at the domestic level. In this light, the examples concerning Germany and Canada show that the role of courts in accommodating normative changes can be very significant. Within the boundaries set by the Constitutions, the courts hold part of the responsibility for establishing the meaning of the law. An important aspect of this competence concerns the interpretation of legislation in light of the fundamental rights protected by the Constitutions. In many legal systems, the courts are allowed to strike down legislative provisions which do not conform to the Constitution. With the increased global emphasis on human rights protection, judiciaries in these systems have thus been 'empowered' vis-à-vis the other branches of government. ${ }^{58}$ It is true that judicial annulment or non-application of legislative provisions for reason of unconstitutionality is prohibited in other legal systems, such as the Netherlands and England ${ }^{59}$ Still, in these systems, judicial review of legislation can take place for reason of fundamental rights protected by international treaties ${ }^{60}$ thus allowing for the 'rights revolution' ${ }^{61}$ to affect these legal systems as well.

As with previous factors of constitutional (in-)flexibility, constitutional conventions play a role alongside a Constitution. Interestingly, both the German and Canadian highest courts have been criticised for their judicial activism when striking down acts of Parliament with an eye to the protection of fundamental rights. ${ }^{62}$ Deference to the legislator in the field of constitutional interpretation therefore still appears to be a powerful constitutional convention. ${ }^{63}$ It should indeed be noted that the distribution of

\footnotetext{
55 Reservations regarding judicial review as opposed to legislative and executive constitutional decisions have been expressed by M. Tushnet, Taking the Constitution Away from the Courts (2000).

56 See for example Solange-I-Beschluss, BVerfG, 29 May 1974, BVerfGE 37, 271 ff.; Solange-IIBeschluss, BVerfG, 22 October 1986, BVerfGE 73, 339.

57 See, inter alia, P. Monahan, Politics and the Constitution: The Charter, Federalism and the Supreme Court of Canada (1987) and E.R. Alexander, 'The Supreme Court of Canada and the Canadian Charter of Rights and Freedoms', 40 University of Toronto Law Journal 1 (1990). More references are available at <http://www.scc-csc.gc.ca/court-cour/biblio/index-eng.asp>; F.M. Bevilacqua, The Supreme Court of Canada: A Politically Legal Role: A Study of the Policy-Making Role of the Courts and the Impact of the Canadian Charter of Rights and Freedoms (1990).

58 See R. Hirschl, Towards Juristocracy: The Origins and Consequences of the New Constitutionalism (2004).

59 On different systems of judicial review in the world, see D. Robertson, The Judge as Political Theorist: Contemporary Constitutional Review (2010) and F. Hamon, La justice constitutionnelle en France et à l'étranger (2011).

60 See hereafter, para. 2.2.4

61 See M. de S.O.l'E. Lasser, Judicial Transformations: The Rights Revolution in the Courts of Europe (2009).

62 Concerning the Bundesverfassungsgericht, see E.L. Barnstedt, 'Judicial Activism in the Practice of the German Federal Constitutional Court: Is the GFCC an Activist Court?', 8 Juridica International 38 (2007); Concerning the Supreme Court of Canada, see R.I. Martin, The Most Dangerous Branch: How the Supreme Court of Canada Has Undermined Our Law and Our Democracy (2005).

63 Regarding the role of national parliaments in the protection of fundamental rights, see V. Barbé, Le rôle du Parlement dans la protection des droits fondamentaux: Etude comparative: Allemagne, France, Royaume-Uni (2009).
} 
competences between the legislator and the judicial branch as regards law-making is a central element of the constitutional culture of liberal-democratic legal systems. This is expressed most clearly in the specific constitutional conventions of these systems. ${ }^{64}$ We have seen that legal systems can be classified according to their conformity to the parliamentary or British model (which is based on the unassailability of legislative acts) or to the constitutional or American model (which allows for judicial review of legislative acts). ${ }^{65} \mathrm{An}$ in-between solution is also possible: the constitutional framework can encompass a degree of flexibility regarding the distribution of competences between the branches of government. In the Canadian legal system, for example, the use of the notwithstanding clause makes it possible to render legislative acts temporarily immune from judicial review in light of certain fundamental rights:

Parliament or the legislature of a province may expressly declare in an Act of Parliament or of the legislature, as the case may be, that the Act or a provision thereof shall operate notwithstanding a provision included in section 2 or sections 7 to 15 of this Charter. ${ }^{66}$

Within the constitutional framework, the use of interpretative competences by the legislator and the judicial branch thus takes place in light of either the principle of sovereignty of Parliament or the principle of judicial review, or sometimes through a balance of these two principles. Furthermore, the use of judicial interpretation depends on the postures or 'philosophies' of individual judges regarding their scope of discretion when deciding difficult cases. ${ }^{67}$ The mix of approaches on a specific panel of judges has an influence on the court's choice between an activist approach and an approach of judicial restraint in individual cases. The development of institutional legal arrangements through interpretative approaches thus is enabled or constrained not only by the constitutional rules regarding the interpreters' competences, but also by the constitutional conventions which underpin these rules.

\subsubsection{The Impact of International Law in the Domestic Legal System}

Finally, the fourth factor determining constitutional (in-)flexibility concerns the role granted to international law in national legal systems. It can be regarded as the 'distinctive function' of constitutions to consider the internal relations within the state, as well as the relations between the national and the transnational legal community. ${ }^{6}$ Through the application of international law in the domestic legal system, normative changes integrated within international legal rules and principles can take effect at the national level.

Two main models which give shape to this implementation of international law can be identified. ${ }^{69}$ Firstly, dualist mechanisms require the transposition of international treaties into national legislation. Examples of such mechanisms can be found in the English, Canadian and US legal systems. Monist mechanisms, by contrast, enable international legal norms to gain effect in the national legal order after the ratification and promulgation of an international treaty. Examples of this can be found in the Netherlands and in France. $^{70}$

International legal rules which give expression to specific normative changes can catalyse the expression of these changes at the level of national legal systems. This catalysis takes place through the taking into account of international legal rules by the

\footnotetext{
64 Concerning legal culture, see inter alia E. Blankenburg, 'Patterns of Legal Culture: The Netherlands Compared to Neighbouring Germany', 46 American Journal of Comparative Law 1 (1998).

65 See also Koopmans, above n. 9.

66 Section 33 of the Canadian Charter of Rights and Freedoms.

67 See A. Barak, The Judge in a Democracy (2008) at 118.

68 Jackson, above n. 20, at 8.

69 On these models and their role regarding the integration of treaties in national legal systems, see M.A. Waters, 'Creeping Monism: The Judicial Trend toward Interpretive Incorporation of Human Rights Treaties’, 107 Columbia Law Review 3 (2007).

70 Articles 93 and 94 of the Dutch Constitution; Article 55 of the French Constitution of 1958.
} 
legislator when elaborating legislative bills. More importantly, international law has an impact on legal development when treaty provisions are used by national courts to set aside legislation in individual cases. ${ }^{71}$ In this respect, normative change can be integrated relatively easily into legal systems in which many international legal rules have authority, either through their direct effect or through their transposition into national law.

Regarding the content of the law, international legal norms may therefore provide an important underpinning or update to the normative framework of national legal systems. This is shown for example by the influence of the ECHR upon the Council of Europe's member states. The application of the Convention by courts in member states and by the European Court of Human Rights (ECtHR) has given rise to significant changes in specific fields of national law, for example through the application of Article 6 ECHR (the right to a fair trial) and Article 8 ECHR (the right to family life). ${ }^{72}$

With the description of this fourth factor, the theoretical framework of constitutional (in-)flexibility is complete. It has become clear that these four factors together can explain the form and speed of the integration of normative change in liberal-democratic legal systems. To assess its explanatory value as regards legal evolution, it is now time to see how this framework functions in practice.

\section{Constitutional (In-)Flexibility and Judicial Globalisation}

The analytical framework of constitutional (in-)flexibility will now be applied to the case of judicial globalisation. This analysis will focus on the normative changes which currently influence the practices of national highest courts in western liberal democracies under the effects of globalisation. The possibilities that specific constitutional frameworks offer in order to integrate these changes into the institutional legal arrangements of highest courts will be outlined. Thus, the way in which the development of institutional legal arrangements is connected with the (in-)flexibility of constitutional frameworks will be clarified.

Firstly, the increased use of foreign law by western highest courts will be examined, outlining the normative changes to the judicial function that this development has given rise to (3.1). Following this, it will be shown how the concept of constitutional (in-) flexibility can ease the accommodation of these normative changes in liberal-democratic legal systems (3.2).

\subsection{The Increasing Judicial Recourse to Foreign Law}

In order to clarify which effects of globalisation have occurred in a specific legal system at moment $t^{\prime}$, a preliminary step will be taken in order to identify the legal context at a previous moment $t$. With regard to the example of judicial globalisation, this requires examining how the recourse to foreign law used to be normatively anchored in liberaldemocratic legal systems, and which changes have occurred in recent years. The resulting developments can then be identified.

Common law constitutions historically appear to be open to judicial exchange of legal ideas when such practice relates to the further development of the common law. Crosscitations between common law courts in different jurisdictions are relatively frequent. ${ }^{73}$ At the same time, a sharp line is drawn between national law and international law,

\footnotetext{
In this respect, regard should be had to the relation between the judge and the legislator in the context of judicial review; see above para. 2.2.3.

${ }^{72}$ See inter alia A.-M. Slaughter, A. Stone Sweet and J.H.H. Weiler (eds.), The European Court and the National Courts: Legal Change in its Social, Political and Economic Context (1998); G. Martinico and O. Pollicino (eds.), The National Judicial Treatment of the ECHR and EU Laws: A Comparative Constitutional Perspective (2010).

73 See Mak, above n. 19.
} 
which is usually integrated into common law systems through a dualist system. ${ }^{74}$ Under the influence of globalisation, it currently appears that:

common law courts are abandoning their traditional dualist orientation and are beginning to utilize unincorporated human rights treaties in their work despite the absence of legislation giving domestic legal effect to the treaties. ${ }^{75}$

Moreover, reference to other foreign legal sources, such as the case law of highest courts in non-common law legal systems, has increased in recent years. In England, the late Lord Bingham was an important advocate of this development. ${ }^{76}$

However, significant differences can be identified between the comparative practices of the courts in common law systems, notwithstanding their similar historical outset. While comparative references are used relatively frequently in the deliberations and judgments of the UK Supreme Court ${ }^{77}$ and the Supreme Court of Canada, ${ }^{78}$ US debate is dominated by resistance to the influence of foreign sources in the domestic legal system. ${ }^{79}$

In continental-European legal systems, binding international and European law has become very influential. In the Netherlands, for example, provisions of the ECHR are invoked in a large number of cases. The popularity of this Convention is related to the prohibition of judicial review of legislation in light of the Constitution. ${ }^{80}$ Given this prohibition, Dutch courts have turned to treaty law in order to ensure the conformity of legislation with fundamental rights. ${ }^{81}$

By contrast, recourse to non-binding foreign legal sources is less utilised in continental-European legal systems as compared to common law systems. Crosscitations between national highest courts in continental-European legal systems are rare. However, recently, reference to other highest courts' case law has obtained some influence in, inter alia, the deliberations of the Supreme Court of the Netherlands (Hoge Raad) and the French Cour de cassation. The Cour de cassation, which is the highest court for civil and criminal law cases in France, has established a practice of requesting help from research laboratories in order to obtain comparative legal research in cases concerning the grands sujets of society (for example, the possibility of same-sex marriage) ${ }^{82}$ The Advocates-General at the Dutch Supreme Court sometimes include comparative legal references in their opinions (conclusies), which advise the Court on the way in which cases before the Court should be decided. ${ }^{83}$ The use of foreign law in judicial deliberations, and sometimes in judgments, often concerns references between jurisdictions with a shared legal heritage. This explains the interest of the Dutch Supreme Court judges in French and German law and case law. ${ }^{84}$

These altered judicial practices in western highest courts suggest that a process of normative change is taking place under the influence of globalisation. Judges seem to have become more aware of foreign law, and an increasing number of judges appear to

\footnotetext{
74 A detailed analysis of the differences between the common law systems, focusing in particular on the UK and Australia, is presented by M. Kirby, 'The Common Law and International Law: A Dynamic Contemporary Dialogue’, 30 Legal Studies 1 (2010).

75 Waters, above n. 69, at 633.

76 T. Bingham, “"There Is a World Elsewhere”: The Changing Perspectives of English Law', 41 The International and Comparative Law Quarterly 3 (1992) and T. Bingham, Widening Horizons: The Influence of Comparative Law and International Law on Domestic Law (2010).

Mak, above n. 19.

78 B. Roy, 'An Empirical Survey of Foreign Jurisprudence and International Instruments in Charter Litigation', 62 University of Toronto Faculty of Law Review 2 (2004).

79 Markesinis and Fedtke, above n. 18.

80 Article 120 of the Dutch Constitution.

81 Mak in Martinico and Pollicino, above n. 72.

82 Cour de cassation, pourvoi no. B 05-16 627, Arrêt no. 511 (Chapin).

83 See, for example, the opinion of Advocate-General Hartkamp concerning the case of Baby Kelly; HR 18 March 2005, NJ 2006, 606 (Baby Kelly). Regarding this case, see also I. Giesen, 'The Use and Influence of Comparative Law in 'Wrongful Life' Cases' (2011), <http://papers.ssrn.com/sol3/papers.cfm?abstract_ id $=1695379$. .

84 Mak, above n. 19.
} 
find it useful to take foreign legal sources into account when deciding cases. However, this judicial recourse to foreign law raises questions on two levels. Firstly, the use of foreign law has an impact on the legitimacy of law and national legal institutions: are judges allowed to look to foreign law when deciding cases, and if so, under which conditions? Secondly, new practices of judicial interpretation might have to be developed, requiring a reflection on methodological issues: when is it useful for judges to take account of foreign law, and how is access to foreign legal sources obtained?

The above-described normative change therefore gives rise to a range of questions concerning its accommodation in the constitutional framework of liberal democracies. It is not the aim of this article to provide a detailed answer to these questions.$^{85}$ Instead, it will attempt to identify how the concept of constitutional (in-)flexibility plays a role in answering these questions.

\subsection{Constitutional (In-)Flexibility in Action}

How does the constitutional framework of a specific national legal system enable the integration of judicial recourse to foreign law into the accepted definition of the judicial function in that legal system? On the one hand, the Constitution as a norm can be implicated in the accommodation of this effect of globalisation. On the other hand, the accommodation of recourse to foreign law can take place at the level of interpretation and application of the Constitution.

\subsubsection{Accommodating Change through Constitutional Norms}

The idea that it is interesting and legitimate for judges to study foreign law is gradually taking hold amongst the constitutional conventions concerning judicial function in western legal systems. ${ }^{86}$ However, in many legal systems, it remains unclear to what extent the Constitution allows for this recourse to foreign law.

Only in South Africa has this trend of judicial globalisation been translated into a constitutional provision, making it mandatory for courts to take account of international law, and allowing for the recourse to foreign law:

39. Interpretation of Bill of Rights

(1) When interpreting the Bill of Rights, a court, tribunal or forum-

(a) must promote the values that underlie an open and democratic society

based on human dignity, equality and freedom;

(b) must consider international law; and

(c) may consider foreign law. ${ }^{87}$

This provision should be considered in relation with South Africa's transition to a liberal-democratic state. The possibility of the use of foreign law, introduced in the country's first democratic Constitution, was thought to offer judges the opportunity to strengthen the authority of their decisions by citing judgments of prestigious courts in established liberal democracies. ${ }^{88}$

In the US, by contrast, a counter-trend can be identified. Resistance to the influence of foreign law exists on the basis of the idea of American exceptionalism, which refers to 'the special character of the United States as a uniquely free nation based

\footnotetext{
85 See in this respect inter alia the Research Project 'Highest Courts in an Internationalising World', initiated by the Hague Institute for the Internationalisation of Law (HiiL); <www.hiil.org>. I myself have also done research on this topic, and am currently preparing a monograph on judicial approaches to the use of foreign law, based on interviews with judges in the Netherlands, the UK, France, Canada and the US.

86 See above, para. 3.1.

87 Article 39 of the Constitution of the Republic of South Africa 1996.

88 See inter alia A. Lollini, 'Legal Argumentation Based on Foreign Law: An Example from Case Law of the South African Constitutional Court', 3 Utrecht Law Review 1 (2007); and U. Bentele, 'Mining for Gold: The Constitutional Court of South Africa's Experience with Comparative Constitutional Law', 37 Georgia Journal of International and Comparative Law 2 (2009).
} 
on democratic ideals and personal liberty’ ${ }^{89}$ Moreover, legislation is currently being prepared in certain states to prohibit courts in these states from considering foreign law when deciding cases. ${ }^{90}$ In Arizona, an amendment to the Arizona Revised Statutes has already been adopted, introducing the following provision:

12-3103. Prohibited enforcement of foreign law

A court, arbitrator, administrative agency or other adjudicative, mediation, or enforcement authority shall not enforce a foreign law if doing so would violate a right guaranteed by the Constitution of this state or of the United States or conflict with the laws of the United States or of this state. ${ }^{91}$

In Arkansas, a similar constitutional amendment has been proposed, supported by the following argument:

The purpose of this Senate Joint Resolution is to amend the Arkansas Constitution concerning the application of foreign laws, legal codes, or systems for the purpose of protecting rights and privileges granted under the United States Constitution and the Arkansas Constitution. ${ }^{92}$

In the US, prohibition on the use of foreign law thus obstructs the integration of normative change which would allow judges to have recourse to foreign law when deciding cases. However, the constitutional amendments seem to leave considerable space for judicial reference to foreign law. After all, the use of foreign law is prohibited only when judges give priority to this law over US federal or state law thereby violating domestic law. The citation of foreign law as a supporting argument for a decision would therefore appear to be permissible.

Other western constitutions do not contain specific rules on the use of non-binding foreign law by judges. The development of this practice is thus left to judges themselves, within the general boundaries regarding judicial interpretation as expressed in the Constitution and its conventions. ${ }^{93}$

Interestingly, the trend of globalisation also appears to have an impact on the significance of national constitutions. Vicki Jackson has argued that:

the growth of the transnational may elicit reactive resort to specifically national constitutions to demarcate a now more contested sphere of national identity and decision-making. Thus, part of the story [Jackson refers here to the "“script" of modernity'94 - EM] has to do with the more specific roles, functions, and attractions of national constitutions. ${ }^{95}$

This renewed emphasis on the national Constitution can be identified in the 2010 report of the State Committee in the Netherlands, which advised on the function and meaning of the Dutch Constitution. The State Committee, chaired by Judge Wilhelmina Thomassen, inter alia, considered adding a general provision to the Constitution, which would express the liberal-democratic character of the Dutch state, the respect and guarantee by the Dutch government of human dignity, fundamental rights and fundamental legal principles, and the value of the rule of law. ${ }^{96}$ The Committee was divided on the question concerning whether the guarantee of constitutional rights and

\footnotetext{
${ }^{89}$ I. Tyrrell, 'What is American Exceptionalism?', <http://iantyrrell.wordpress.com/papers-andcomments/>.

90 <http://gaveltogavel.us/site/2011/05/03/bans-on-court-use-of-shariainternational-law-law-in-arizonabills-advance-in-missouri-and-texas-failing-in-most-states/>.

91 Bill H.B. 2064, signed by the Governor of Arizona on 12 April 2011. See <http://www.azleg.gov>.

92 Arkansas SJR 10 (Constitutional Amendment), available at <http://www.arkleg.state.ar.us>.

93 See hereafter, para. 3.2.2.

94 T. Ginsburg, Judicial Review in New Democracies: Constitutional Courts in Asian Cases (2003) at 26, quoting J.W. Meyer et al., 'World Society and the Nation State', 103 American Journal of Sociology 1 (1997).

95 Jackson, above n. 20, at 3.

96 Staatscommissie Grondwet, Rapport Staatscommissie Grondwet (2010), at 40.
} 
principles should be reinforced by adding conditions to the Constitution regarding the judicial application of international law.97

These examples show that national constitutions form an important locus for the integration of normative change induced by judicial globalisation. The Constitution can explicitly prescribe or prohibit the use of international and foreign law, as well as regulating the priority attributed to domestic and foreign law. It can also remain silent and thus leave space for judicial discretion regarding the use of non-binding foreign legal sources. The introduction of constitutional amendments regarding these issues appears to be influenced by developments in the political or societal context of a state. For example, an amendment regarding the use of international or foreign law is only taken into consideration when very significant developments occur in the political or social life of the community. ${ }^{98}$ This corroborates the predominant convention that the Constitution should guarantee the stability of the government. ${ }^{99}$

This analysis of the first and second factors of constitutional (in-)flexibility, concerning the detail of constitutional norms and the modalities for their revision, shows how judicial globalisation is enabled or constrained at the level of the Constitution. Another part of the explanation for the development of institutional legal arrangements under the effects of judicial globalisation concerns the argumentative framework for judicial decision-making.

\subsubsection{Accommodating Change through the Interpretation and Application of the Constitution}

Changes in judicial practices under the effects of globalisation can also be understood by considering the third and fourth factors of constitutional (in-)flexibility, namely the approach to constitutional interpretation and the impact granted to international law in national legal systems.

As regards the interpretation of the constitutionally defined judicial function, it seems that the definition of this function is silently altered by judges themselves. Judges are increasingly seen to embrace the idea that non-binding foreign legal sources can be considered in judicial deliberations. In the English legal system, this idea underlies the Practice Direction (Citation of Authorities), which contains the following instruction on judicial interpretation:

9.1 Cases decided in other jurisdictions can, if properly used be a valuable source of law in this jurisdiction. At the same time, however, such authority should not be cited without proper consideration of whether it does indeed add to the existing body of law. ${ }^{100}$

In the absence of specific guidelines, judges in other legal systems have developed a personal approach to the use of foreign law. A very open approach is advocated by Aharon Barak, the former President of the Supreme Court of Israel. He has stated that:

When a national jurist - a judge, a professor of law, or an attorney - is confronted with the need to understand a legal phenomenon - for example, "what is law?"; "what is a right?”; "what is a legal person?”; "what is the relationship between morality and law?” - that jurist is certainly permitted,

\footnotetext{
97 Id., at 128. Following up on the report, the current Dutch government has decided to propose only a minor constitutional amendment (regarding Article 13 of the Constitution); Letter of the Minister of the Interior and Kingdom Relations, 24 October 2011, available at <http://www.rijksoverheid.nl/onderwerpen/ grondwet-en-statuut/documenten-en-publicaties/kamerstukken/2011/10/24/kabinetsreactie-adviesstaatscommissie-grondwet-11-november-2010.html>.

98 Regarding the US, see M. Rosenfeld, 'Principle or Ideology? A Comparativist Perspective on the U.S. Controversy over Supreme Court Citations to Foreign Authorities', Cardozo Legal Studies Research Paper, no. 213, in particular at 21-27 (2008) (addressing the influence of constitutional and national identity on the acceptance of the judicial use of foreign law).

99 See above, paras. 2.1 and 2.2.2.

100 [2001] 1 W.L.R. 1001 (Sup. Ct.). See also J. Lee, 'Confusio: Reference to Roman Law in the House of Lords and the Development of English Private Law’, 5 Roman Legal Tradition 24, at 33 (2009).
} 
and it is even desirable, to examine the understanding of legal phenomena and legal concepts beyond his national framework. These are all universal aspects which cross national boundaries, and in order to understand them, it is worthwhile to turn to all thought which has been developed on the subject, be its geographical origin as it may. So did our forefathers through the years. And so did Holmes, Cardozo (judges), Roscoe Pound, Hohfeld, Fuller, Llewellyn (professors), and many others. They did not shut themselves inside of their national borders. The entire world was before them. ${ }^{101}$

By contrast, Justice Scalia of the US Supreme Court has vehemently condemned the judicial search for inspiration outside of the national legal framework. In his dissenting opinion in the case of Roper v. Simmons, ${ }^{102}$ which concerned the constitutionality of the juvenile death penalty, Scalia presented the following argument regarding the use of foreign law in judicial decision-making:

Though the views of our own citizens are essentially irrelevant to the Court's decision today, the views of other countries and the so-called international community take center stage. ... the basic premise of the Court's argument - that American law should conform to the laws of the rest of the world - ought to be rejected out of hand. ... I do not believe that approval by "other nations and peoples" should buttress our commitment to American principles any more than (what should logically follow) disapproval by "other nations and peoples" should weaken that commitment. ... What these foreign sources "affirm", rather than repudiate, is the Justices" own notion of how the world ought to be, and their diktat that it shall be so henceforth in America. The Court's parting attempt to downplay the significance of its extensive discussion of foreign law is unconvincing. "Acknowledgment" of foreign approval has no place in the legal opinion of this Court unless it is part of the basis for the Court's judgment - which is surely what it parades as today. ${ }^{103}$

Depending on the approach which is predominant among judges in a specific legal system (in particular in the highest courts), foreign law will either be enabled or constrained in becoming a source of inspiration for judicial decision-making of this legal system.

Another change concerns the development of judicial practices in light of the growth of international law. In this respect, the ECHR can be identified as a major influence. The application of treaty provisions by national courts has been the motor behind the development of harmonised human rights protection across Europe. The involvement of national highest courts in the development of the national law on the basis of the ECHR, the case law of the ECtHR and exchanges of ideas with other states party to the treaty is an example of legal convergence which emphasises the role of international law in the process of legal development in national legal systems. ${ }^{104}$ Supreme Court judges in the UK and in the Netherlands acknowledge the impact of ECHR and EU law in their decision-making, and the change of attitude which this internationalisation of the domestic law has inspired in their courts. ${ }^{105}$

In summary, at the level of the interpretation and application of the Constitution, the development of judicial practices under the effects of globalisation is visible in the gradual adaptation of the interpretative approaches of individual judges and the highest courts. In each legal system, this adaptation is either enabled or constrained by constitutional norms and conventions involved in judicial decision-making. The exchange of legal ideas across national borders is stimulated by the impact of international law and the

\footnotetext{
101 A. Barak, 'Comparative Law, Originalism and the Role of a Judge in a Democracy: A Reply to Justice Scalia', speech for the Fulbright Convention, 29 January 2006.

102543 U.S. 551 (2005).

103543 U.S. 551 (2005), Roper v. Simmons, dissenting opinion of Justice Scalia, at 16-23.

104 See also Jackson, above n. 20 (arguing that possible attitudes towards globalisation include resistance, the aim of convergence, and the aim of engagement with foreign law).

105 See Mak, above n. 19.
} 
case law of international courts upon domestic legal systems, which has created a platform for transnational judicial dialogue. ${ }^{106}$ Again, the constitutional (in-)flexibility of national legal systems proves to be able to account for the form and speed of legal development induced by normative change.

The above analysis has enabled us to establish the explanatory value of the concept of constitutional (in-)flexibility. Moreover, it has revealed that this trend of globalisation is affecting the constitutional rules and conventions of liberal democracies on a scale not seen before. This development has opened up many new pathways for constitutional theoretical research. In light of this article's methodological point of departure, it makes sense to broaden our view, and consider how constitutional theory itself can be further developed in the current, swiftly evolving legal context.

\section{New Paths for Constitutional Theoretical Research}

The trend of globalisation does not only have implications for the judicial function in liberal democracies. It affects both the understanding and functioning of constitutions. Constitutional theorists have therefore been encouraged to develop an agenda for research in order to give guidance concerning the future development of legal arrangements for the institutions of government, including the courts, in this evolving global legal context. New analytical frameworks - or shifting 'paradigms' ${ }^{107}$ - can be identified, which constitutional legal theorists look to in order to explain and guide legal development in this globalised legal context. Some of these frameworks will be mentioned here in order to give a clearer idea of the course which constitutional theoretical research is currently taking.

First of all, the globalisation of the law and public decision-making has induced the development of a changing concept of the 'state'. In the era of globalisation, it is felt that the traditional conception of states as the locus of public power does not capture the impact at the national level of legal sources originating at different levels of governance. Constitutional theory attempts to develop a more accurate concept for the current age. Patrick Glenn, for example, has defined the state as 'an epistemic community which is able to deal with normative information originating in different sources' ${ }^{108}$

Concerning the notion of law, research in the global legal context focuses on the shared substance of laws rather than on the authority which produced these laws. The locus of public power is regarded as less significant for the identification of rules applicable in the local context. The scope of public power may be further-reaching, since the intertwinement of systems of governance has created new platforms through which actors with public power can influence one another. ${ }^{109}$ In this context, the old concept of common laws - which refers not only to the Anglo-Saxon common law, but also to for example Roman-Dutch law - is regaining popularity through aiding the explanation of trends of legal harmonisation across national borders. ${ }^{110}$ Amongst the most prominent theories first developed in the context of the European Union legal order is the theory of 'constitutional pluralism'. This focuses on the shared but different constitutional foundations of legal systems. ${ }^{111}$

Theories of global governance are also gaining support. These focus on the regulatory mechanisms which are developing across borders. These theories claim that global governance is of an administrative nature rather than of a constitutional nature. ${ }^{112}$ As

\footnotetext{
106 See the HiiL project, above n. 85.

107 See T.S. Kuhn, The Structure of Scientific Revolutions (1996).

$108<$ http://www.hiil.org/organ-bios/patrick-glenn>. This idea is developed further in Glenn's forthcoming book The Cosmopolitan State. Regarding the concept of 'epistemic communities', see also Glenn (2007), above n. 15.

109 See A.M. Slaughter, A New World Order (2005).

110 See H.P. Glenn, On Common Laws (2007).

111 N. Walker, 'The Idea of Constitutional Pluralism', 65 The Modern Law Review 3 (2002).

112 N. Krisch and B. Kingsbury, 'Introduction: Global Governance and Global Administrative Law in the International Legal Order’, 17 European Journal of International Law 1 (2006). On the Global Administrative Law (GAL) Project in general, see <http://www.iilj.org/GAL/>.
} 
concerns the form and speed of the development of regulation at the transnational level, it has been observed that legal development occurs in some fields while other areas of law remain largely untouched. No unified body of regulation exists. ${ }^{113}$

A recent contribution to the development of constitutional theory, concerning specific postures of transnational constitutionalism, has been made by Vicki Jackson. Her theory of 'constitutional engagement' emerges from the idea that theories of resistance to global influences, as well as theories of cross-border convergence of laws, are descriptively too narrow in order to fully capture the changing functions of constitutions and courts in the global legal context. ${ }^{114}$ Jackson introduces the concept of constitutional engagement, defining transnational sources as 'interlocutors' in judicial decision-making. Her aim is therefore to offer a better explanation of the changes induced by globalisation, and to establish which possibilities and pitfalls should be dealt with when engaging with the transnational. ${ }^{115}$

Finally, concerning legal reasoning, constitutional theory and legal theory have been used to explain changes concerning processes of deliberation and judgment of national courts. Mitchel Lasser has used the distinction between unified and bifurcated styles of judicial deliberations to identify similarities and differences between the judicial decision-making of the US Supreme Court, the French Cour de cassation and the European Court of Justice. ${ }^{116}$ In his second book, he has used the idea of internal and external constraints on judicial decision-making to analyse the development of judicial decision-making processes in France in light of the evolution of human rights protection in Europe. ${ }^{117}$

The richness of these new directions in research shows that constitutional theory allows for a better understanding of legal evolution. The process of legal evolution, in turn, stimulates the further development of constitutional theoretical research.

\section{Conclusion}

Judges in the national highest courts in Western liberal democracies are increasingly called upon to interpret legal rules which originate outside of the national legal system. In light of this development, they have become more interested than before in learning about the legal ideas and experiences of judges in other legal systems. This article has sought to clarify how the conception of the judicial function and the institutional set-up of western highest courts can be adapted in order to accommodate this change. In this way, more insight has been obtained as to the possibilities which constitutional theory offers for the understanding of legal evolution, in particular as concerns the development of legal institutional arrangements in liberal democracies.

The concept of constitutional (in-)flexibility has been presented as an analytical tool through which to study the development of the constitutional underpinnings of the judicial function. This concept, which encompasses four factors, explains how normative changes are accommodated in national legal systems through these systems' constitutional frameworks. The concept takes account of cultural aspects relating to the constitutional conventions of the legal system, including judicial philosophies concerning the scope of the judicial role in the balance of powers. It has been shown how this concept of constitutional (in-)flexibility can be used to explain judicial globalisation and other processes of normative change which affect legal systems. The analysis made clear that a specific process of legal evolution, in turn, can open up new directions for constitutional theoretical research.

\footnotetext{
113 See B. Kingsbury, N. Krisch and R.B. Stewart, 'The Emergence of Global Administrative Law', 68 Law and Contemporary Problems 3, at 15 (2005).

114 Jackson, above n. 20. See also V.C. Jackson, 'Constitutional Comparison: Convergence, Resistance, Engagement', 119 Harvard Law Review 1 (2005).

115 Id.

116 M. de S.O.l'E. Lasser, Judicial Deliberations: A Comparative Analysis of Judicial Transparency and Legitimacy (2005).

117 Lasser, above n. 61.
} 
Constitutional theory can thus be said to make a valuable contribution to the understanding of a specific process of legal evolution. Its approach can also be developed to give guidance for the future, by highlighting the considerations needed 'to keep the Constitution responsive to changing social conditions'.118

118 S.A. Barber and J.E. Fleming, Constitutional Interpretation: The Basic Questions (2007). 